
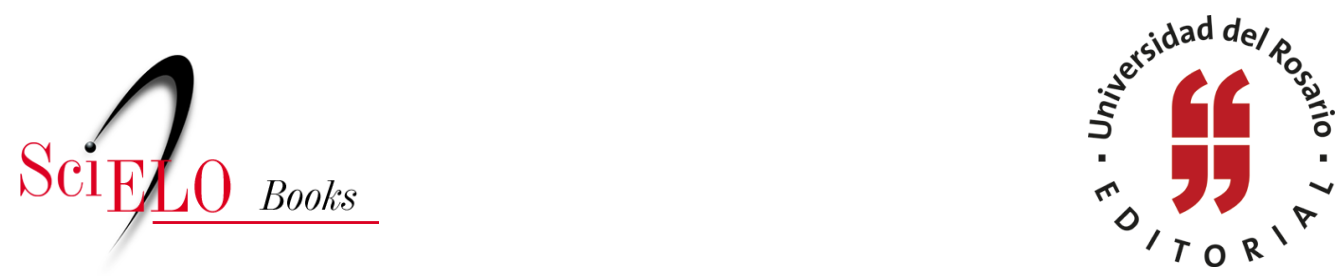

\title{
El 9 de abril en la memoria visual de Colombia del Bogotazo al Día Nacional de la Memoria y de la Solidaridad con las Víctimas
}

\author{
Sven Schuster
}

\section{SciELO Books / SciELO Livros / SciELO Libros}

SCHUSTER, S., ed. El 9 de abril en la memoria visual de Colombia: del Bogotazo al Día Nacional de la Memoria y de la Solidaridad con las Víctimas. In: La nación expuesta. Cultura visual y procesos de formación de la nación en América Latina [online]. Bogotá: Editorial Universidad del Rosario, 2014, pp. 43-67. Textos de ciencias humanas collection. ISBN: 978-958-738-524-3. https://doi.org/10.7476/9789587385243.0004.

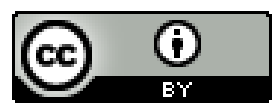

All the contents of this work, except where otherwise noted, is licensed under a Creative Commons Attribution 4.0 International license.

Todo o conteúdo deste trabalho, exceto quando houver ressalva, é publicado sob a licença Creative Commons Atribição 4.0.

Todo el contenido de esta obra, excepto donde se indique lo contrario, está bajo licencia de la licencia Creative Commons Reconocimento 4.0. 


\title{
El 9 de abril en la memoria visual de Colombia: del Bogotazo al Día Nacional de la Memoria y de la Solidaridad con las Víctimas
}

\author{
Sven Schuster \\ Universidad del Rosario
}

En 2012, la fecha del 9 de abril, hasta entonces conocida como el día del Bogotazo, fue oficialmente rebautizada como Día Nacional de la Memoria y de la Solidaridad con las Víctimas. De esta manera, el Estado colombiano cumplió su "deber de memoria”, estipulado en el artículo 142 de la Ley 1448 de 2011. ${ }^{1}$ Esta decisión fue motivada por el deseo de ampliar el sentido de la conmemoración de los sucesos sangrientos del 9 de abril de 1948 en Bogotá y hacer de los hechos un elemento central de una nueva narración nacional. Así, el asesinato de Jorge Eliécer Gaitán y la consiguiente destrucción de una gran parte del centro de Bogotá marcaron el comienzo de una espiral de violencia cuyas consecuencias se hacen sentir todavía hoy. Dentro de las víctimas conmemoradas también se encontrarían — por lo menos teóricamente - las víctimas de La Violencia, ${ }^{2}$ o sea, de la guerra civil no declarada de los años cincuenta y sesenta. No obstante, como demuestran las conmemoraciones oficiales y no oficiales desde los años sesenta hasta nuestros días, eso no es el caso.

1 Según la Ley 1448 de 2011 (Ley de Víctimas y Restitución de Tierras), el Congreso de la República se reunirá el 9 de abril de cada año para celebrar el Día Nacional de la Memoria y de la Solidaridad con las Víctimas, y escuchará a las víctimas del conflicto armado en una jornada de sesión permanente. Aparte de eso, habrá actos simbólicos en todo el país.

2 El término La Violencia designa la guerra civil en Colombia entre 1946 y 1963, y siempre se escribe en mayúsculas. 
Aunque la denominación de la fecha haya cambiado, lo que se conmemora hoy en día es el Bogotazo y no la guerra histórica que originó el actual conflicto armado interno. ¿A qué se debe eso? ¿Por qué la memoria de La Violencia convergió con la memoria del 9 de abril? Y, sobre todo, ¿cuál fue el papel de los medios visuales en este proceso, de reducir una época histórica tan compleja a una sola fecha?

\section{El 9 de abril y La Violencia entre memoria y olvido}

El 9 de abril de 1948, a la una y cinco de la tarde, Juan Roa Sierra disparó cuatro veces contra el político liberal Jorge Eliécer Gaitán, quien estaba saliendo de su oficina en el centro de Bogotá. El asesino fue linchado poco después por una turba furiosa, así que no sabemos nada sobre su posible motivación. De todos modos, parece verosímil la versión según la cual Roa no era un mercenario partidista, sino un enfermo mental que sufría de fuertes alucinaciones (Semana 2006). Con Gaitán también murió la esperanza de un país más justo y libre de corrupción, como lo estaban soñando los miles de seguidores del liberalismo popular que habían perdido su líder idolatrado. Gaitán, quien decía de sí mismo que "no era un hombre sino un pueblo", ya habría preparado a sus discípulos para la eventualidad de un atentado contra su vida, pues él mismo esperaba que en caso de su asesinato ninguna piedra de Bogotá quedara encima de la otra (Braun 2008, 265).

En un ambiente caracterizado por luchas partidistas entre las dos unidades políticas tradicionales de Colombia (los liberales y los conservadores), la muerte de Gaitán era como la chispa que hizo estallar el barril de pólvora. Ya desde 1946 se reportaron luchas entre grupos liberales y conservadores en el campo. Estos enfrentamientos tuvieron su origen en la división del Partido Liberal durante la campaña electoral de 1946. Aunque el partido fuera más fuerte que en épocas anteriores y reuniera un mayor número de seguidores, estos estaban divididos entre el político reformista Eduardo Santos y el más radical Gaitán, quien mostró fuertes tendencias populistas. Además, las sangrientas luchas partidistas de la campaña electoral de 1930 aún no habían sido olvidadas. Para muchos partidarios había llegado la hora de la venganza. La muerte de Gaitán, candidato presidencial liberal para las elecciones de 1950, no marcaba entonces el inicio de La Violencia, sino su primera culminación. El día del asesinato, una multitud furiosa quemó y saqueó el centro de Bogotá.

Después de varios días de lucha y pillaje, alrededor de 2500 personas habían muerto. Tropas auxiliares, así como bandas paramilitares del departamento de Boyacá, los tristemente célebres chulavitas, fueron llamadas por los dirigentes 
conservadores para apaciguar las llamas de la contienda. Aunque la élite conservadora y liberal, unida en su miedo de la protesta popular, consiguiera sofocar el levantamiento de manera rápida y sangrienta, la victoria fue efímera y se limitó apenas a la capital. A la población de las regiones rurales del país, sobre todo en los departamentos de Tolima, Huila, Antioquia, Santander y Chocó, les esperaba todavía lo peor: La Violencia. En el transcurso de los años entre 1948 y 1963, alrededor de 200.000 colombianos encontraron la muerte. Lo que comenzó como una lucha partidista según los moldes de los conflictos decimonónicos, parecía cada vez más un conflicto social e ideologizado. Las ideas marxistas, presentes en Colombia desde los años veinte, se universalizaron a partir de 1959 en el contexto de la revolución cubana. En esa última fase del conflicto, después del bombardeo del enclave comunista de Marquetalia y la consiguiente formación de las Fuerzas Armadas Revolucionarias de Colombia (FARC), en 1964, La Violencia se transformó en "las violencias".

En nuestros días, el panorama del conflicto colombiano se caracteriza por varios actores violentos, como los grupos guerrilleros izquierdistas, los paramilitares derechistas y los narcotraficantes. Hoy, en el marco de nuevas conversaciones de paz con el gobierno, las FARC son la última organización armada ilegal, cuyo origen remonta directamente a la época de La Violencia. Sin embargo, la mayoría de los colombianos sabe poco sobre las raíces de este grupo. Es como si uno de los episodios más traumáticos de la historia reciente hubiera sido borrado de la memoria colectiva (Pécaut 2013, 180 y ss.). El 9 de abril y la memoria de Gaitán, no obstante, están bastante vivos, como muestran las constantes conmemoraciones en forma de películas, monumentos, libros, museos, marchas, charlas académicas y obras de arte. De hecho, después de Simón Bolívar, la figura de Gaitán es la que tiene más monumentos en Colombia. Así, por ejemplo, el municipio de Puerto Gaitán fue llamado en su honor, tal como un teatro en Bogotá; incluso el billete de 1000 pesos muestra imágenes y algunas frases célebres del "caudillo" liberal (figura 1).

¿A qué se debe este fenómeno? ¿Por qué la memoria de La Violencia, un conflicto que ocurrió sobre todo en el campo, entre campesinos analfabetas que obedecían órdenes de sus respectivos partidos, convergió con la memoria del 9 de abril? En su libro Guerras, memoria e historia, publicado por primera vez en 2003, el historiador y "violentólogo" Gonzalo Sánchez comenta este fenómeno de la siguiente manera: 


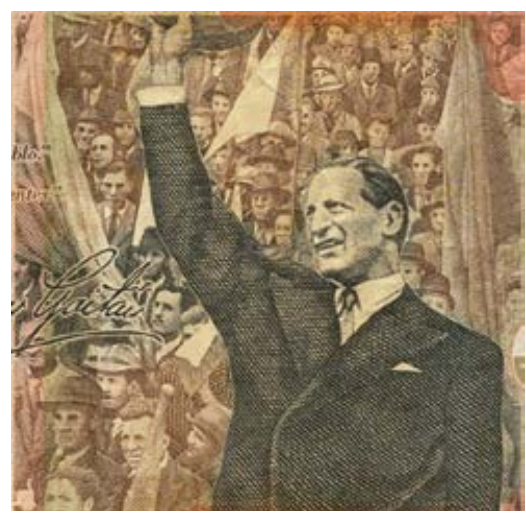

Figura 1. Billete de 1000 pesos (detalle)

Todo parecería como si el único muerto reconocible por su nombre fuera Gaitán, o como si todos los demás, los 200.000, se diluyeran en él. Gaitán, símbolo de la unidad del pueblo en la plaza, en la acción política, es también el símbolo de unidad en la muerte. En cierto modo, la memoria de Gaitán personifica y al mismo tiempo anula la memoria de los demás. $(2006,87)$

A pesar del señalamiento de Sánchez, todavía hay pocos esfuerzos serios de conmemorar la época de La Violencia, muy al contrario de lo que ocurre con el 9 de abril. Diez años después de su constatación sobre la dilución de La Violencia con el culto al "caudillo" liberal, el mismo Sánchez parece haberse conformado con las representaciones ahistóricas del 9 de abril. Al defender la declaración del Día Nacional de la Memoria y de la Solidaridad con las Víctimas, Sánchez reconoce la integración de los "ecos de la Violencia” en una nueva narración histórica que se está constituyendo en los últimos años en Colombia, en el marco de un verdadero boom de memoria (Antequera Guzmán 2011, 92 y ss.). Como director del Grupo de Memoria Histórica de la Comisión Nacional de Reparación y Reconciliación (CNRR), incluso está dispuesto a aceptar que "habrá nuevas resonancias superpuestas a esos ecos originales":

La Ley de Víctimas y Restitución de Tierras relanzó su capacidad expresiva. El 9 de abril no es solo referente de las víctimas de ayer, sino también de las víctimas de hoy. Además, despojado ahora de su original sello partidista, se instala en un horizonte de futuro y de realización de tareas pendientes. No es que desaparezcan 
los ecos de la Violencia de los años cincuenta en la conmemoración, sino que en adelante en la movilización conmemorativa habrá nuevas resonancias superpuestas a esos ecos originales. Nuevos íconos, nuevos convocantes, nuevos discursos, nuevos rituales, nuevas prácticas y movilizaciones conmemorativas se irán instalando con el paso del tiempo. (Sánchez 2012)

¿Eso no significa que la memoria de La Violencia está definitivamente borrada, sin chance de ser institucionalizada, de ser transformada en memoria histórica? Aunque esa época no cumpla un papel importante en la memoria histórica institucionalizada, el 9 de abril está más presente que nunca. Mientras se están construyendo nuevos museos y centros de memoria en todo el país, La Violencia, entendida como fenómeno histórico y social complejo, no ocupa mucho espacio en los libros de texto. Aunque la producción académica sobre la temática sea enorme, poco se ha hecho para discutir las raíces y las consecuencias del conflicto en el espacio público. Eso se debe, en primer lugar, a la responsabilidad histórica de los dos partidos tradicionales como principales instigadores de La Violencia. En un país con una continuidad política tan excepcional como Colombia, donde el monopolio del bipartidismo se prolongó hasta los años noventa, ningún político oficialista estaba dispuesto a exigir la conmemoración de una época tan "vergonzosa”, tal vez con implicaciones negativas para él mismo o algún miembro de su familia. En vez de eso, se instauraron las "políticas del olvido" (Schuster 2009).

En este sentido, no parece extraño que nuevos lugares de memoria no se distingan tanto de obras pasadas cuyos creadores mostraron poco interés por La Violencia. Muy a menudo, se trata de proyectos altamente politizados, cuyo enfoque está en la violencia política de los últimos treinta años; el nuevo Centro del Bicentenario: Memoria, Paz y Reconciliación, de la Secretaría de Gobierno de Bogotá, dedica una sala entera a la época de La Violencia, diferenciándose así de otros centros y museos. A pesar de esta excepción notable, todavía es demasiado temprano para indagar sobre el impacto de esta prometedora representación y para saber de qué manera tratarán el tema otros centros de memoria, como la proyectada Casa de la Memoria en Medellín o el futuro Museo Nacional de la Memoria (Antequera Guzmán 2011, 92 y ss.). Hasta ahora, el 9 de abril generalmente ha sido presentado como punto de partida para el ciclo de violencia que azota el país desde 1948 y se ha dejado de lado el contexto histórico más amplio. En este sentido, por ejemplo, el Museo Casa Gaitán, inaugurado en los años ochenta durante la presidencia de Virgilio Barco (1986-1990), así como la presentación oficialista 
de la "historia patria" en el Museo Nacional de Colombia, reduce la época de La Violencia a la fecha del 9 de abril.

También el mencionado Centro de Memoria de Bogotá, inaugurado en junio de 2013, está fuertemente conectado con los sucesos del 9 abril. Por medio de la arquitectura se establece una continuidad temporal y espacial con el conflicto del presente, ya que no es por casualidad que el edificio esté hecho de tierra, como aclaró el alcalde Gustavo Petro: "Este es un edificio que se construyó con tierra para decirle, de manera simbólica a Colombia y a Bogotá, que es precisamente la tierra, la causa de la violencia en el país" (Alcaldía Mayor de Bogotá 2012).

En este sentido, no sorprende que la mayor parte de las exposiciones temáticas del Centro gire alrededor de la violencia política desde los años ochenta, por ejemplo las desapariciones, los asesinatos de los miembros de la Unión Patriótica (UP), o la problemática del despojo de tierras por las bandas paramilitares oficialmente “desmovilizadas". En el futuro próximo, el Centro contendrá más de 40.000 testimonios, fotografías, objetos y mensajes de las víctimas del conflicto armado, los cuales podrán ser consultados en un archivo, que quedará disponible en la red y en sus instalaciones físicas. Como el expartido de Petro, el izquierdista Polo Democrático Alternativo ( $\mathrm{PDA}$ ) está detrás del proyecto, las actividades museológicas se enfocan en la denuncia y la conmemoración de los crímenes del paramilitarismo, del Estado y de los narcotraficantes, y no tanto en las atrocidades cometidas por la izquierda radical. ${ }^{3}$

A pesar de su politización aparente, el Centro se destaca como un poderoso lugar de memoria por su ubicación, pues el predio se encuentra justo encima de la parte del Cementerio Central de Bogotá, donde supuestamente una gran parte de las víctimas del Bogotazo habría sido enterrada de manera precaria, en los días posteriores a la revuelta (figura 2). Es también interesante saber que, a diferencia de otros proyectos parecidos en el pasado, los responsables de la construcción se preocuparon por excavar y trasladar los cadáveres encontrados antes de comenzar la obra. Todos los restos mortales no identificados recibieron una sepultura digna en otras partes del Cementerio Central (Londoño Calle 2011).

3 Entre 2005 y 2010, Petro era miembro del PDA. En octubre de 2011 se afilió al Movimiento Progresista. 


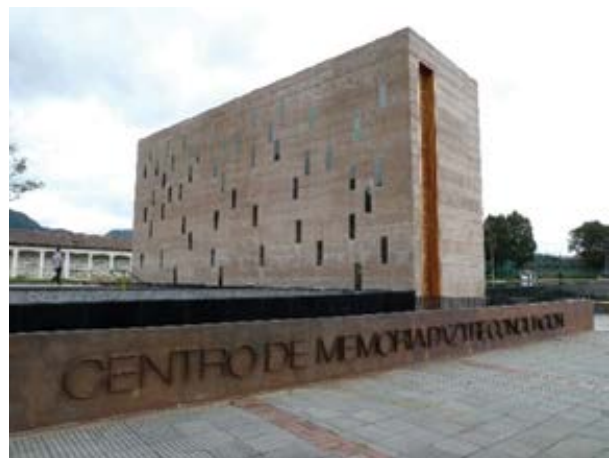

Figura 2. Centro del Bicentenario: Memoria, Paz y Reconciliación de la Secretaría de Gobierno de Bogotá Fuente: fotografía del autor.

De este modo, se construyó un lazo simbólico entre el presente y el pasado, o sea, entre las fosas comunes de los paramilitares modernos y aquellas de los chulavitas de los años cincuenta. La figura de Gaitán, sin embargo, representa el comienzo de la violencia en el país y, a la vez, nos recuerda la lucha del "pueblo oprimido" contra la élite oligárquica. Dentro del proyecto político del PDA y sus seguidores, el líder liberal asesinado simboliza justicia e igualdad social. No obstante, aspectos más negativos, por ejemplo, su retórica inflamatoria y manipuladora, su inclinación por el fascismo italiano o su desprecio por ciertas manifestaciones demasiado "populares" no son tematizados (Braun 2008, 128-137; Pécaut 2013, 185).

Sin embargo, representaciones históricas politizadas como esta no son un fenómeno nuevo. De hecho, la politización del 9 de abril comenzó pocos meses después de los sucesos sangrientos en Bogotá en 1948. En esa primera fase de La Violencia, las élites políticas se apoderaron de la figura de Gaitán y la instrumentalizaron para tapar la dimensión socioeconómica de la guerra. Así, los aspectos más "incómodos" del conflicto fueron reducidos a una sola fecha.

En este contexto nació una nueva cultura visual que pretendía ser crítica y vanguardista al mismo tiempo, pero cuyos representantes artísticos no siempre consiguieron esclarecer el fenómeno de La Violencia. Así, como el conflicto ni siquiera recibía un nombre adecuado, como si se tratara de una catástrofe natural, tampoco parecía posible representarlo por medio del arte, salvo pocas excepciones. En realidad, surgió una cultura visual urbana que muchas veces dejaba entrever su desinterés por lo que estaba ocurriendo en la "periferia” rural del país. El 9 de abril, por otro lado, enseguida impulsó la creatividad de una nueva generación de artistas, cuya producción impregnó profundamente el devenir del arte latinoamericano del 
siglo Xx. Algunas de las obras de los pintores aquí analizados -Débora Arango, Alejandro Obregón, Alipio Jaramillo y Enrique Grau - se volvieron canónicas, aunque no siempre en el momento de su producción. Junto con el imaginario creado por los políticos liberales y conservadores, sus interpretaciones del 9 de abril han desempeñado un papel importante en el proceso de transformar la fecha en un hito histórico, en el cual diluyen veinte años de barbarie. Sin embargo, antes de analizar con más detalle las representaciones del 9 de abril en la pintura, indago un poco sobre la relación entre memoria e imagen.

\section{Memoria e imagen}

Bajo el término memoria histórica, como la definió Maurice Halbwachs en los años treinta y cuarenta, se puede entender la elevación de la memoria a un ámbito institucional. Su contraparte, la más conocida memoria colectiva, es un fenómeno esencialmente social y de duración mediana (ochenta a cienta años). Cuando un grupo social pequeño, es decir, una comunidad fácilmente reconocible, de pocos miembros y de dos o tres generaciones, deja de existir, también deja de existir la memoria colectiva, mientras la memoria histórica sigue viva (Halbwachs 2004).

El concepto de los lugares de memoria, el cual ya fue mencionado brevemente al tratar sobre la misión del Centro de Memoria de Bogotá, se remonta a la obra de Pierre Nora (1984-1992), quien por su vez recuperó las ideas de Halbwachs en los años ochenta. Según Nora, un lugar de memoria es un núcleo significativo (tanto material como inmaterial, y de larga duración a través de las generaciones) para la memoria y la identidad colectivas. Este núcleo se caracteriza por una fuerte carga de simbolismo o de emoción. Está arraigado en las convenciones y costumbres sociales, culturales, y políticas. Se modifica en la medida en que cambian las maneras de su recepción, apropiación, uso y tradición. En breve: los lugares de memoria son estabilizadores de la memoria colectiva y pueden ser de carácter muy diverso: monumentos, paisajes, medios audiovisuales, lugares comunes, refranes, creencias populares, fechas, etc. Se trata de fenómenos culturales relacionados consciente o inconscientemente con el pasado o con la identidad nacional.

Así, parece evidente que el 9 de abril es más que una fecha; es un lugar de memoria que cumple definidas funciones sociales y políticas. Por medio de constantes luchas y debates, su conmemoración gana un sentido específico para ciertos grupos colectivos. Este proceso de constantes luchas por el sentido del pasado es de suma relevancia para poder hablar de lugares de memoria, y no de una especie de "memoria muerta”, es decir, de monumentos u otras objetivaciones, cuyo significado 
original está olvidado. Los medios impresos, los medios audiovisuales, las puestas en escena, los monumentos y las imágenes en general cumplen un papel fundamental en este proceso, como nos recuerda Rolf Reichardt (2006). Según él, la repetición permanente de imágenes que comparten un origen común o que forman parte de una serie mínimamente coherente ejerce poder sobre los productores y los receptores, a la vez. Podemos identificar esquemas visuales cargados de sentido, los cuales — con el tiempo - se transforman en elementos de la memoria colectiva. En este sentido, Reichardt sostiene que, después de cierto tiempo, tales imágenes podrían ser "activadas" por meras alusiones, lo cual posibilitaría la formación de "discursos visuales sofisticados" (2006, 226).

Martin Warnke (2003), compartiendo y ampliando estas ideas, destaca la función pública de imágenes que fueron producidas explícitamente para impactar en el espacio público. Tales “imágenes públicas”, sobre todo creadas por arquitectos, pintores y escultores, pueden ser comprendidas como "señales políticas", cuyos productores quieren transmitir un mensaje político que se sustente frente a la opinión pública durante algún tiempo. Para poder entender e indagar sobre lo que él llama iconografía política, es importante saber algo sobre los comendadores, los patrocinadores, el tema elegido y los receptores de la obra analizada. Para Warnke, los comendadores siempre deben considerar los deseos y las expectativas de los receptores, cuyas percepciones normativas muchas veces aparecen como parte integral de una obra de arte.

En este sentido, las imágenes aquí analizadas fueron producidas con el deseo explícito de servir como antídoto contra el olvido. Se trataba de lugares de memoria, cuyos creadores también respondieron a sentimientos más generalizados de una parte de la población urbana. Esos cuadros formaron entonces parte de los discursos de su época, reflejan la mentalidad de la clase media urbana y cumplieron una función política al provocar debates amplios e incluso censura.

\section{El 9 de abril en la pintura}

Pese a que las "políticas del olvido" han influenciado nuestra manera de ver el 9 de abril, siempre existieron voces críticas que reclamaron el derecho de contar otra historia. Sobre todo, en la esfera del arte podemos observar desde muy temprano un tratamiento de los hechos históricos que pretende distinguirse de la versión oficial en la cual los acontecimientos son interpretados como el resultado de las demandas "irracionales" de un pueblo "salvaje y embrutecido", o en caso de algunos 
conservadores, como el producto de una conspiración comunista. En fin, ¿el joven Fidel Castro no estaba en Bogotá aquel día? ${ }^{4}$

Aunque estas versiones carezcan de veracidad histórica y solo servían para encubrir la responsabilidad de las élites políticas, estas maneras de interpretar el 9 de abril sobreviven hasta hoy. La Violencia, no obstante, no forma parte de esta historia distorsionada. Aunque desde las esferas del arte, del cine o de la literatura hubiera innumerables voces que asumieron desde entonces la tarea de representar, interpretar y reinterpretar los hechos violentos que se iban transformando con el tiempo en una parte integral de la autoimagen nacional de los colombianos, la mayoría de ellos se conformó con reproducir las imágenes ya conocidas sobre el Bogotazo.

Una de las primeras artistas en representar los sucesos sangrientos era la antioqueña Débora Arango (1907-2005), cuya obra mantiene un lugar notable en la memoria visual del país. Fue ella quien denunció con más intensidad los horrores de aquel día, y que — a diferencia de muchos otros pintores - también pintó algunos cuadros sobre La Violencia. Precisamente por su posición crítica hacia las clases dirigentes y su feminismo combativo, su obra fue descalificada y rechazada por las academias de arte durante mucho tiempo. Solo en los últimos treinta años, en un proceso paralelo a la deconstrucción de la historia oficial hecho por investigadores, intelectuales, artistas y escritores, sus acuarelas y óleos fueron revalorizados paulatinamente. A diferencia del impacto limitado de la mayoría de los estudios académicos de las últimas décadas, la obra de Arango ha conquistado el espacio público nacional e internacional. Debido a las duras controversias y debates que generó su arte, sus pinturas representan un verdadero lugar de memoria, es decir, son elementos sustitutivos materiales, cuya función es la conservación de la memoria colectiva perdida.

Muy impresionada con la revolución estilística introducida por los muralistas mexicanos, Débora Arango, quien pertenecía a la alta burguesía de Medellín, se acercó a este género en los años treinta, aunque inclinándose hacia trazos gruesos, figuras idealizadas, superficies amplias y rasgos desenfocados. Hasta los años cuarenta su motivo preferido fue el cuerpo femenino desnudo, una obsesión que culminó en una serie de cuadros sobre las prostitutas de su ciudad. En algunos de estos óleos, esta feminista temprana muestra a los hombres como animales com-

4 Sobre la “conspiración comunista” véase Schuster $(2009,108-111)$. 
pulsivos, y acusa a la vez la hipocresía del Estado y la Iglesia al tratar el "problema” de la prostitución con el único fin de someter a la mujer por medio de un discurso moralizante. A medida que sus reflexiones artísticas y personales crecían, las posibilidades muralistas evolucionaban y se reflejaban en planes para realizar un gran mural en algún espacio público. No obstante, a causa de sus controvertidas obras sobre el maltrato de la mujer, la administración conservadora de Medellín se negó a prestarle ayuda financiera, pues a diferencia de su ya aceptado "maestro" Pedro Nel Gómez, Arango se había vuelto una "feminista rebelde" y, por lo tanto, el blanco preferido de las críticas de la burguesía paisa (Londoño Vélez 1997, 136 y ss.).

De la misma manera, se armó un escándalo en 1940, cuando sus desnudos femeninos se volvieron tema de un airado debate en el Congreso de la República. Como amiga de Amparo Jaramillo, la esposa de Jorge Eliécer Gaitán, Arango ya había provocado reacciones hostiles por parte de políticos y clérigos conservadores en varias ocasiones. Aunque el obispo de Medellín le había advertido personalmente de abstenerse a pintar "obscenidades”, aceptó una invitación personal de Gaitán a exponer una serie de acuarelas en el Teatro Colón de Bogotá, las cuales celebraban el cuerpo femenino y, en algunos casos, también el sexo femenino. Encolerizado por aquel increíble acto de "degeneración artística", el político conservador Laureano Gómez se refirió a la exposición durante un debate parlamentario para atacar a su rival Gaitán, el entonces ministro de Educación (1940-1942). También El Siglo, periódico de la propiedad de Gómez, descalificó la obra de Arango en términos moralizantes y la rechazó como técnicamente inferior y hasta pornográfica. En palabras de un columnista, se trataba de un "atentado contra la cultura y la tradición artística” de la capital del país (El Siglo 1940).

Debido al gran alboroto público y mediático que había causado la exposición, Arango se vio forzada a descolgar sus cuadros después de solo dos días. En los años siguientes se dedica aún más a la denuncia social, en gran parte incentivada por los sucesos del 9 de abril. A partir de 1954 Arango profundizó su formación artística en la renombrada Academia San Fernando, en Madrid, donde organizó otra exposición controvertida el 28 de febrero de 1955, y que tuvo que ser cerrada por órdenes de las autoridades franquistas, cuya visión del "buen arte" no se diferenciaba en nada del ideal gomecista (Londoño Vélez 1997, 191 y 192). Esta vez, la muestra solo duró un día. Después de varias estadías extensas en el extranjero, la artista se alejó cada vez más de la vida pública y su obra cayó en el olvido. Solo a mediados de los años setenta comenzó el lento proceso de revalorización de sus pinturas, como muestra la exitosa exposición Arte y política, que tuvo lugar en 1975 en el Museo de Arte 
Moderno de Bogotá (Mambo), y en la cual también se presentaron artistas más jóvenes (Zea 1994, 34). Actualmente, copias de algunos de sus cuadros sobre La Violencia también se pueden apreciar en el Centro de Memoria de Bogotá. A pesar del paulatino redescubrimiento de la obra de Débora Arango, algunos historiadores del arte más tradicionales hasta hace poco se negaron a incorporar sus cuadros en los cánones y las supuestas obras "estándares" de la historia del arte en Colombia. ${ }^{5}$

A pesar de una larga historia de negligencia y censura, su obra finalmente llegó a formar parte del "patrimonio cultural nacional". De todos modos, para las generaciones venideras el valor de sus cuadros no consiste tanto en las técnicas de pintura o su estética peculiar, sino más bien en las temáticas políticas y sociales que los clasifican como importantes medios de la memoria cultural: son testigos de una época oscura, cuyos detalles aún no forman parte de la maltratada memoria histórica oficial, erigida, instalada e impresa en forma de monumentos, museos y libros.

Así, su acuarela Masacre del 9 de abril (1948) es considerada una de las representaciones más impactantes del Bogotazo. Al igual que otras bien conocidas variaciones del tema, se encuentra hoy en día en un sinnúmero de catálogos, libros e incluso en algunos manuales escolares con el fin de contextualizar los sucesos del 9 de abril (Bravo y Fernández Uribe 2006, 7 y ss.). El cuadro se compone de un campanario en estilo barroco, vista típica en el centro de Bogotá. Encima de la torre hay una mujer escasamente vestida, muy probablemente una prostituta, como también indican las declaraciones de Arango con respecto al cuadro. La mujer está tocando las campanas, mientras unas monjas se deslizan por la ventana del lado derecho. En la parte izquierda de la acuarela se retratan dos soldados en el acto de penetrar con sus bayonetas a uno de los alzados. En la calle que colinda con el convento vemos, además, cómo dos hombres arrastran el cadáver profanado del asesino de Gaitán por el suelo. Otras personas con palos afilados se encuentran justo debajo del chapitel. Todos tienen caras agresivas y hasta deformadas. En el centro del cuadro un grupo de alzados sostiene, e incluso "presenta” al observador, un cadáver en una angarilla, probablemente el cuerpo de Gaitán. Parecen decididos a tomar la torre para matar a los soldados allí refugiados. La filiación política de los atacantes se aclara por una pancarta en la cual resplandece la frase "Viva Gaitán” (figura 3).

5 Así, por ejemplo, los editores del Diccionario de artistas en Colombia (1979) o de la voluminosa Historia del arte colombiano (1983). 


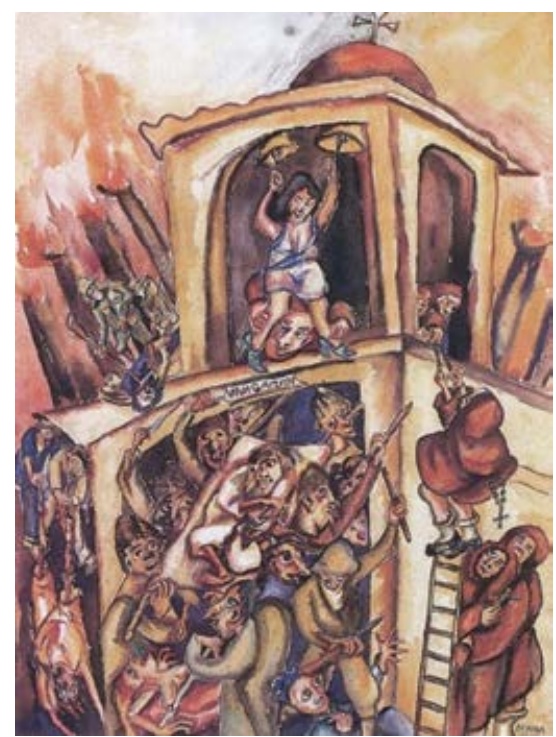

Figura 3. Débora Arango, 1948, Masacre del 9 de abril, (acuarela, $77 \times 57 \mathrm{~cm}$, Museo de Arte Moderno de Medellín)

Una descripción más densa de los horrores del 9 de abril es difícilmente imaginable. Por medio de sus trazos gruesos y expresivos, Arango cubre con exceso casi todas las figuras y crea así una imagen estereotípica del Bogotazo. Sin embargo, el cuadro no es una glorificación del "pueblo" o de los "gaitanistas", como suele ser el caso con tantas representaciones del tema. Al contrario, su acuarela muestra al "pueblo" como una masa irracional e incontrolable, cuyos gestos son salvajes y cuyas caras están distorsionadas. Es de suponer que algunas fotografías del cadáver de Gaitán, difundidas por la prensa capitalina inmediatamente después de su deceso, le pudieron servir de fuente de inspiración a la artista. Gaitán, quien aún estaba con vida después de los disparos de Roa Sierra, había muerto en el camino hacia el hospital, donde su cadáver fue expuesto en una camilla para los fotógrafos (Braun 2008, 134 y ss.).

La verdadera "masacre", a la cual se refiere el título del cuadro, ocurre al margen izquierdo, encima del techo del convento, y es perpetrada por los soldados del gobierno. Como otro elemento característico de su obra, tampoco faltan las alusiones irónicas hacia la Iglesia. Sin embargo, queda al observador cómo quiere interpretar las expresiones disturbadas en las caras de las monjas al ver por entre los hábitos de su hermana que se desliza de la torre. 
A diferencia de los seguidores fieles del muralismo mexicano, Débora Arango nunca tomó una posición política abierta y se distanció de las posturas del realismo socialista que estaba de moda entre los muralistas de la época. Por esta razón, también intentó evitar representaciones moralizantes y dualistas. Cuando María Cristina Laverde le preguntó en 1986 qué opinaba de las discusiones sobre sus cuadros, muchas veces motivadas por asuntos de política partidista y si veía alguna diferencia sustancial entre los partidos tradicionales en Colombia, la artista contestó de la siguiente manera: "En los dos partidos hay de todo y si existen diferencias es más a nivel de personas. Pienso que casos como el mío, se utilizan para atacar al otro, como sucedió con Jorge Eliécer Gaitán por parte de Laureano Gómez" (Laverde 2004, 41).

Se confirma, entonces, que Débora Arango, aunque se vio a sí misma como una persona apolítica, dirigió la crítica inherente en muchos de sus cuadros hacia el sistema bipartidista en general, acercándose de esta manera al discurso gaitanista y su famosa oposición entre el "país político" y el "país nacional”. Este desprecio abierto hacia la clase política también explica por qué la censura no solo atacó sus desnudos, sino también su representación del 9 de abril. Además, el carácter político de su obra, así como su intención de denunciar la situación social y política en el país, quedan comprobados con su proyecto nunca realizado de transformar Masacre del 9 de abril en mural. Según declaró, tal obra habría servido para que mucha gente se diera cuenta de lo absurdo de la lucha sangrienta entre conservadores y liberales. No obstante, sus planes se vieron frustrados por el rechazo colectivo de las élites políticas tradicionales, que se negaron a financiar un proyecto de este tipo:

Yo tenía mucha facilidad para pintar en acuarela y llegar de esta al mural, es muy fácil. En un mural se puede expresar más que en un cuadro. Mira, cuando mataron a Gaitán, no había televisión, por supuesto, y me puse a escuchar por radio todo lo que sucedía en Bogotá: la forma como asesinaron a Gaitán, lo ocurrido con su asesino, las mujeres en las torres de las iglesias echando a volar las campanas, las monjas saliéndose de los conventos [...]. Todo lo que describían lo iba pintando. Sin darme cuenta terminé haciendo un boceto para 'fresco' [Masacre del 9 de abril] y me repetía “ $i$ Ay, que algún día yo pueda convertir esto en un Mural! Mucha gente entendería a través de él, el significado de esta absurda violencia”. Jamás lo logré [...]. (Laverde 2004, 41) 
$\mathrm{Al}$ igual que Arango, el más renombrado Alejandro Obregón (1920-1992) se destacó con un óleo sobre los sucesos del 9 de abril. Su cuadro Masacre del 10 de abril también es considerado una de las obras más emblemáticas sobre el Bogotazo y ha sido reproducido en folletos, libros de texto e innumerables catálogos.

A diferencia de Arango, no obstante, Obregón nunca tuvo que luchar contra la censura. Mientras que los cuadros de Arango eran en gran parte desdeñados por el establishment artístico, a finales de los años cincuenta Obregón ya era el pintor comercialmente más exitoso y afamado de Colombia. Aunque algunos de sus cuadros también muestren aspectos de la violencia política de la última fase de La Violencia, su obra no provocó el mismo rechazo que las pinturas de Arango. ¿A qué se debe eso?

En primer lugar, la pintora paisa pertenecía a otra generación de artistas cuyos representantes aún estaban fuertemente influenciados por la pintura académica europea. Su estilo artístico y, sobre todo, el tratamiento "atrevido" de temas altamente politizados no solo suscitaron la ira de las élites políticas, sino también la de muchos artistas. Cuando Obregón, quien había inmigrado en los años veinte desde Barcelona, comenzó a pintar en los años cuarenta, el rechazo de los círculos conservadores y clericales hacia todo lo "moderno" todavía se hizo sentir. Así, como en el caso de los cuadros de Arango, la prensa conservadora solo tenía palabras de desprecio para la obra de artistas modernos como Alipio Jaramillo o Ignacio Gómez Jaramillo (Medina 1999a, 23). En esa época, no obstante, Alejandro Obregón, quien ya estaba experimentando con nuevas técnicas y estilos que había conocido en Estados Unidos y en Europa, era un artista prácticamente desconocido en Colombia.

Solo a partir de la segunda mitad de los años cincuenta, después de su retorno de Francia donde había permanecido entre 1949 y 1954, Obregón se estableció en el pequeño mundo del arte colombiano. Al igual que Débora Arango, Obregón formaba parte de la alta burguesía, pues su padre era el dueño de una fábrica de tejidos en Barranquilla y le habría gustado ver a su hijo como sucesor. Este, sin embargo, eligió una vida de aventurero que lo iba a llevar finalmente a la pintura. A diferencia de Arango, ya sus primeras obras de los años cuarenta fueron reseñadas de manera positiva por la prensa que lo tildó de "expresionista romántico" (Jaramillo 2001). Esta denominación particular tenía que ver con su fascinación temprana por la flora y la fauna de Sudamérica, cuya magia ambivalente lo tenía atrapado en esa fase de su proceso creativo. Así, pintaba plantas carnívoras, volcanes en erupción y cóndores majestuosos, generalmente en estilo cubista o expresionista. 
Los hechos del 9 de abril, sin embargo, lo impactaron de una manera tan profunda que sentía la necesidad inminente de denunciar las atrocidades cometidas contra el pueblo (Medina 1999b, 8 y 9). A diferencia de Arango, ese día Obregón en efecto se encontraba en Bogotá donde pudo presenciar los sucesos violentos. El día después de las luchas callejeras, o sea el 10 de abril, Obregón fue para el Cementerio Central donde soldados y voluntarios ya habían depuesto cientos de cadáveres, como también ilustra una fotografía impresionante de Luis Gaitán (“Lunga”), quien trabajaba en la Jornada, el diario liberal fundado por Jorge Eliécer Gaitán (figura 4). Debido al peligro de una epidemia y por causa de las condiciones higiénicas precarias, algunas de las cerca de 2500 víctimas del Bogotazo fueron enterradas allá en fosas comunes (Braun 2008, 331 y 332 ).

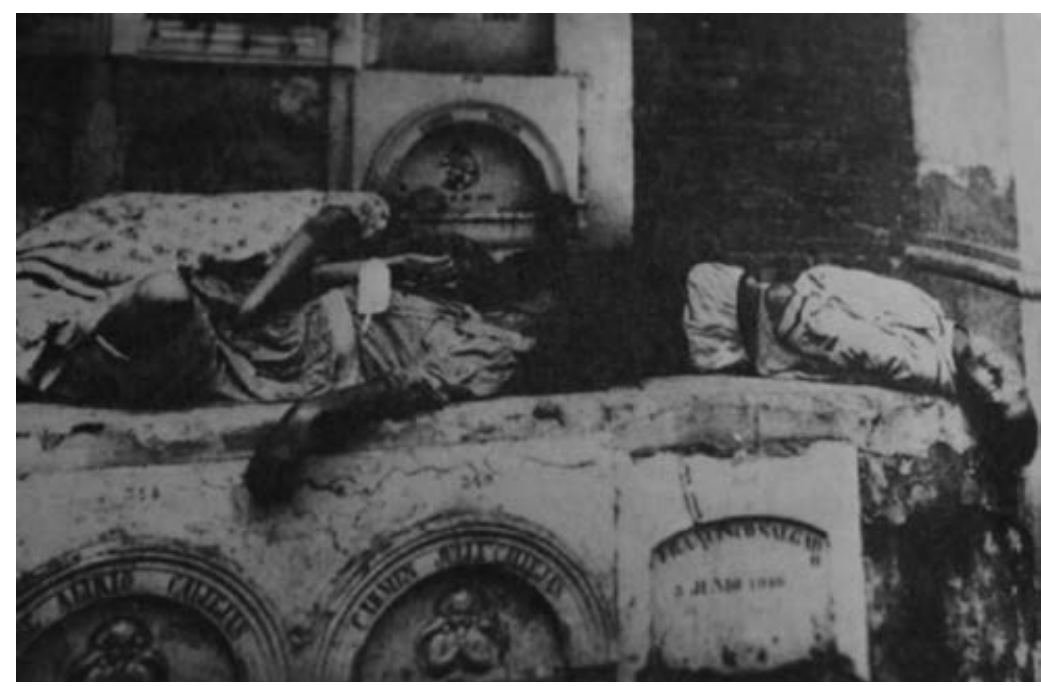

Figura 4. Lunga, 1948, Cementerio Central

Fuente: Braun (1985)

Al parecer, Obregón pasó varias horas en aquel lugar tenebroso para elaborar esbozos. Finalmente, decidió transformar los hechos violentos en un óleo de grandes dimensiones, el cual muestra una influencia notable del Guernica (1937) de Picasso. Como Obregón había estado en Barcelona entre 1940 y 1944, ampliando sus capacidades artísticas en la Academia La Llotja, estaba fuertemente influenciado por la obra de pintores españoles como Goya (Los desastres de la guerra, 1810-1814) y Picasso. A diferencia de Arango, le interesaron no tanto los sucesos del 9 de abril, sino sus consecuencias terribles. Al igual que en la singular obra de 
Picasso, que denunciaba el bombardeo de la ciudad vasca de Gernika por la fuerza aérea alemana durante la Guerra Civil Española y que se había transformado en monumento universal contra la guerra, Obregón entendió su cuadro como advertencia enfática sobre las consecuencias posibles de una agravación del conflicto en Colombia (Jaramillo 2001). Los años venideros de la guerra civil no declarada iban a mostrar lo acertado de su postura.

A diferencia de sus obras tardías de los años sesenta y setenta, las cuales eran mayoritariamente figurativas y consumibles para un público más amplio, sus cuadros de los años cuarenta, por lo general, eran abstractos y monocromáticos. En este sentido, Masacre del 10 de abril representa una excepción, ya que muestra con plasticidad los cadáveres humanos que dejó la masacre cometida por las tropas del gobierno y los chulavitas.

Una serie de fotografías históricas, e incluso algunas imágenes cinematográficas, ilustran de manera inequívoca cómo los gaitanistas atacaron a los soldados con armas bastante primitivas. En varios lugares del centro de Bogotá, la así llamada Jega (seguidores de Jorge Eliécer Gaitán) entró en tiendas para armarse con cuchillos, machetes y palos de madera. Sus adversarios, no obstante, estaban equipados con rifles modernos y pistolas. Aparte de eso, los temidos chulavitas habían ocupado lugares estratégicos en los techos de las casas donde actuaron como francotiradores. Aunque muchos soldados y policías cambiaron de lado durante la revuelta, parece probable que los grupos aliados al gobierno conservador del presidente Mariano Ospina Pérez (1946-1950) eran responsables por la mayor parte de los muertos (Braun 2008, 330-337).

Obregón subraya este hecho mostrando los cuerpos de las víctimas con pequeñas heridas de bala. Los rostros de los asesinados —incluidos niños y mujeresexpresan dolor y sufrimiento aun en la muerte, y nos recuerdan la impiedad de los victimarios. Además, las tres figuras centrales del cuadro: un cuerpo femenino pintado en matices oscuros, el cuerpo torcido de un recién nacido y el cadáver de una mujer embarazada simbolizan la negación de la vida en general. La violencia desatada aquel día ni siquiera mostró respeto por la vida no nacida, lo cual transformó a Colombia en un país estéril y sin futuro (figura 5).

Sin embargo, en 1948 el cuadro no estimuló ningún debate sobre culpa y expiación, como lo habría esperado su creador (Medina 1999b, 8 y 9). Al fin y al cabo, la élite política también se mostraba asustada con la "locura colectiva de las masas bárbaras", por lo cual entendieron o, mejor dicho, quisieron entender los 


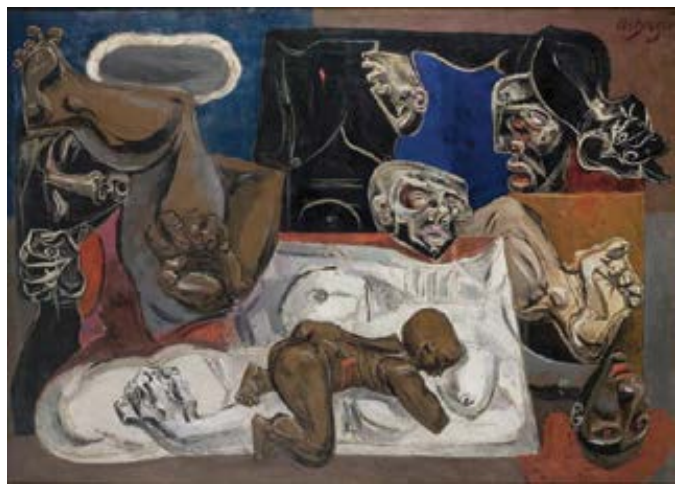

Figura 5. Alejandro Obregón, 1948, Masacre del 10 de abril, (óleo sobre tela, $104 \times 145 \mathrm{~cm}$, Sociedad Colombiana de Arquitectos)

cuadros de Obregón y Arango como una crítica de la "irracionalidad” de las masas y no de sí misma.

Hoy en día, Masacre del 10 de abril, junto a un retrato de Gaitán de Alipio Jaramillo (1913-1999), se encuentra en una sala del Museo Nacional de Colombia dedicada al Bogotazo. ${ }^{6}$ El problema es que esta exposición permanente, como tantas otras, se limita exclusivamente a los hechos del 9 de abril, sin mencionar el contexto más amplio de La Violencia. Aunque Obregón había pintado varios cuadros sobre esta, de los cuales se destaca La Violencia (1962), la reducción de la guerra civil a los hechos sangrientos del 9 de abril en el Museo Nacional es sintomática para la cultura de la memoria en Colombia.

En la placa que acompaña el retrato de Gaitán, pintado por Jaramillo según los criterios estilísticos del realismo socialista y reflejando la imagen "popular" que Gaitán se había construido conscientemente, exaltando su rasgos gruesos y su piel obscura (Braun 2008, 167-175),7 se puede leer: "Su muerte y los acontecimientos que la sucedieron marcan el hito más importante y trágico de la historia del siglo Xx

6 De todos modos, es muy probable que la presentación de esta sala cambie pronto, ya que el museo se encuentra actualmente $(2014 / 2015)$ en un proceso de reestructuración. En lo referente a la historia contemporánea, es posible que la nueva sala, Memoria y Nación, ofrezca una perspectiva diferente sobre el Bogotazo y La Violencia.

7 Braun comenta la construcción de la autoimagen "popular" de la siguiente manera: "Todo lo que de físico había en Gaitán se volvió profundamente simbólico [...]. Al comenzar la campaña le dio instrucciones a Daniel Rodríguez, un fotógrafo de Bogotá, para que lo hiciera aparecer lo más feo posible en la fotografía inicial. La mayoría de sus retratos muestran a un Gaitán de tez oscura, con los 
en Colombia". Sin embargo, las consecuencias “importantes y trágicas" que aquellos acontecimientos tuvieron para una gran parte de los campesinos colombianos no son mencionadas ni visualizadas en el museo (figura 6).

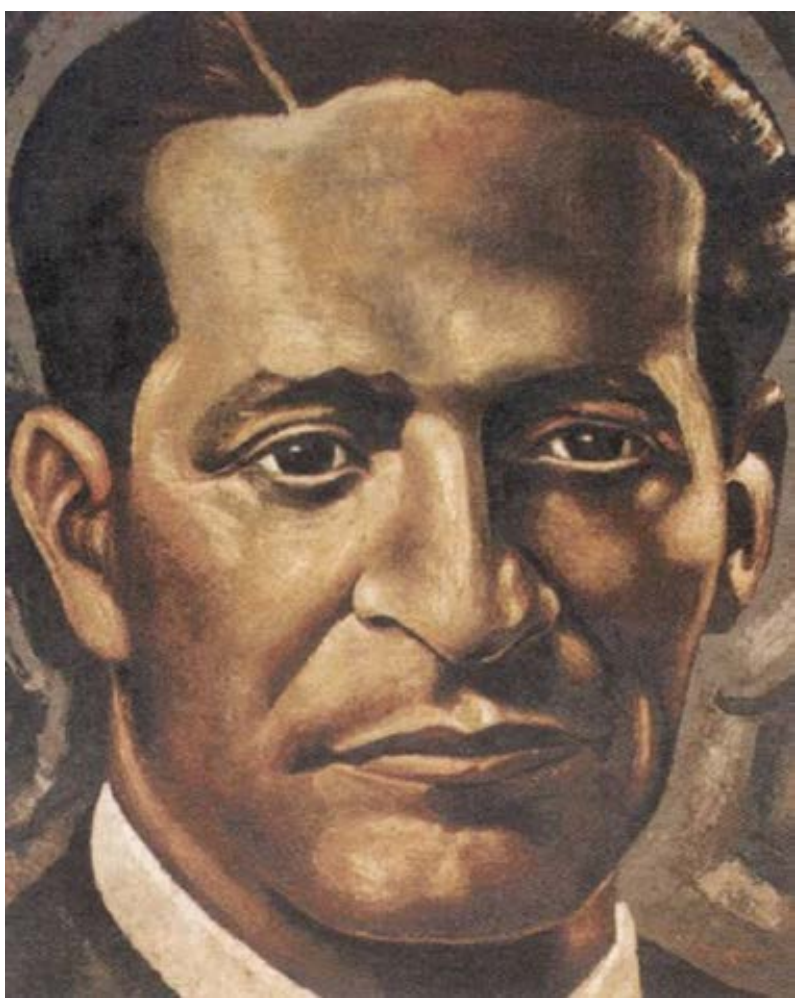

Figura 6. Alipio Jaramillo, 1948, Jorge Eliécer Gaitán, (óleo sobre madeflex, $162 \times 122 \mathrm{~cm}$,

Colección de Artes Plásticas, Banco de la República, Bogotá, registro 210)

En 1948, el mismo Jaramillo contribuyó con otra representación de la "masacre" del 9 abril, aunque esta resulta menos conocida que los cuadros de Arango y Obregón. A diferencia de su retrato de líder liberal, el cual fue presentado al público de la capital en noviembre de 1948 durante el primer acto conmemorativo de

ojos entrecerrados, en un signo culturalmente reconocible de sospecha y desconfianza considerado característico de la 'malicia indígena"' $(2008,168)$.

8 Para algunas informaciones generales sobre el cuadro, véase la página del Museo Nacional (http:// www.museonacional.gov.co/paginaindependientesfebrero03jorgeeliecergaitan). 
Gaitán en el Teatro Municipal, y por lo tanto cumplió desde temprano una función pública, su 9 de abril ni siquiera iba a encontrar un lugar duradero en Colombia. Según informaciones de la casa de subastas Christie's, el cuadro fue rematado en 2010 por 110.500 dólares. ${ }^{9}$

Al igual que Débora Arango, el enigmático Jaramillo, quien vivía muy retirado y evitaba cualquier tipo de publicidad, mostró la lucha entre los grupos armados de la derecha (los cuales, por lo tanto, aparecen en la parte derecha del cuadro) y la Jega, a la izquierda. En realidad, no se puede hablar de "lucha", ya que el cuadro en su dualismo crudo, inspirado por el muralismo mexicano, muestra los seguidores de Gaitán como víctimas indefensas de los grupos aliados al presidente Ospina. Al igual que Obregón, pero con mucho menos capacidad técnica, Jaramillo también enfoca la eliminación de la vida en general, simbolizada por la mujer embarazada y agonizante al lado izquierdo. Aunque no se trate de una gran obra, el cuadro sirve para ejemplificar otras tantas imágenes dualísticas producidas en el contexto del 9 de abril (figura 7).

Un último ejemplo interesante de la reducción visual de La Violencia al 9 de abril es el cuadro Tranvía incendiado, de Enrique Grau (1920-2004), quien, por lo general, no se destacaba por tratar temas políticos. Su pintura tiene que ser vista dentro de un discurso visual más amplio, pues una de las imágenes más evocadas sobre el Bogotazo es la destrucción de los tranvías. Captado en innumerables fotografías históricas, prácticamente todos los bogotanos tienen hasta hoy conciencia sobre la pérdida de este modo de transporte que se extinguió poco después de los actos de vandalismo del 9 de abril. Incluso los bogotanos que no conocen estas fotos recuerdan al tranvía al observar los restos de los carriles en el centro de Bogotá (figura 8). Como medida consciente de crear una conexión entre el paisaje urbano presente y el pasado sangriento, estos carriles también representan un lugar de memoria. Sin embargo, lo que muchos bogotanos ignoran es que no todos los tranvías fueron realmente destruidos por la turba furiosa, como nos hizo creer la historiografía oficial durante décadas. Al contrario, en muchos casos fueron los dueños de las empresas de autobuses quienes aprovecharon el desorden generalizado para deshacerse de una competencia no deseada. Con éxito, como sabemos hoy (Zambrano e Iriarte 1988, 72 y ss.).

9 Según informaciones de Christie’s (http://www.christies.com/lotfinder/paintings/alipio-jaramillo9-de-abril-5370313-details.aspx). 


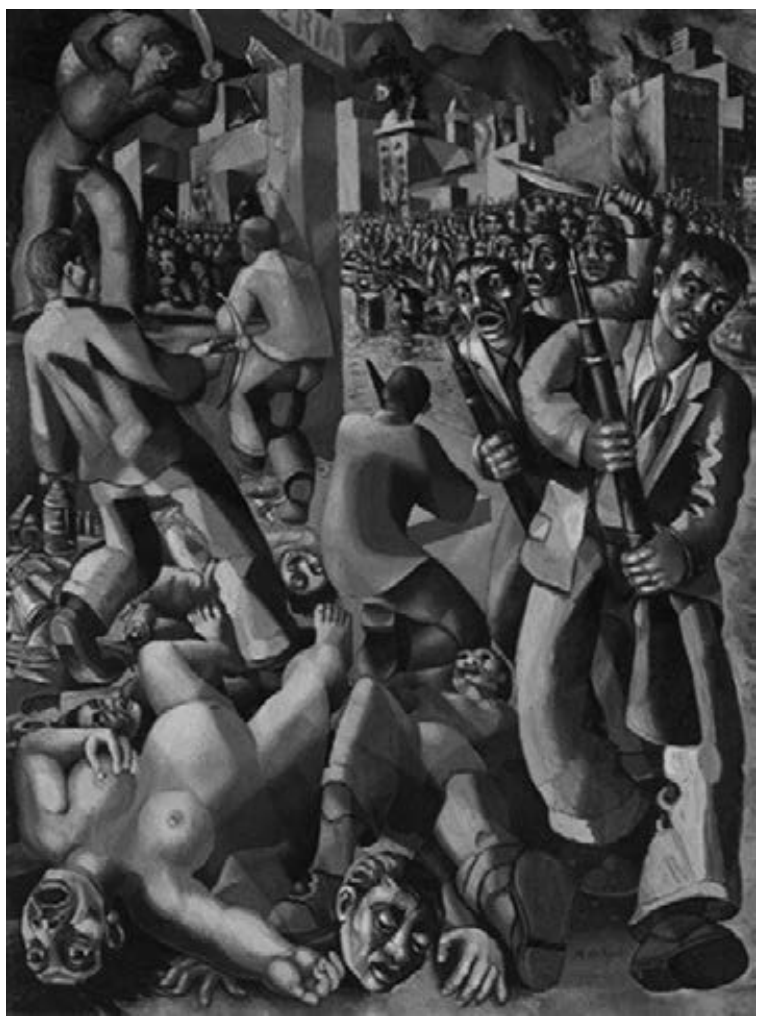

Figura 7. Alipio Jaramillo, 1948, 9 de abril, (óleo sobre plancha de fibra dura, $121 \times 90 \mathrm{~cm}$ ) Fuente: Medina y Zea (1999).

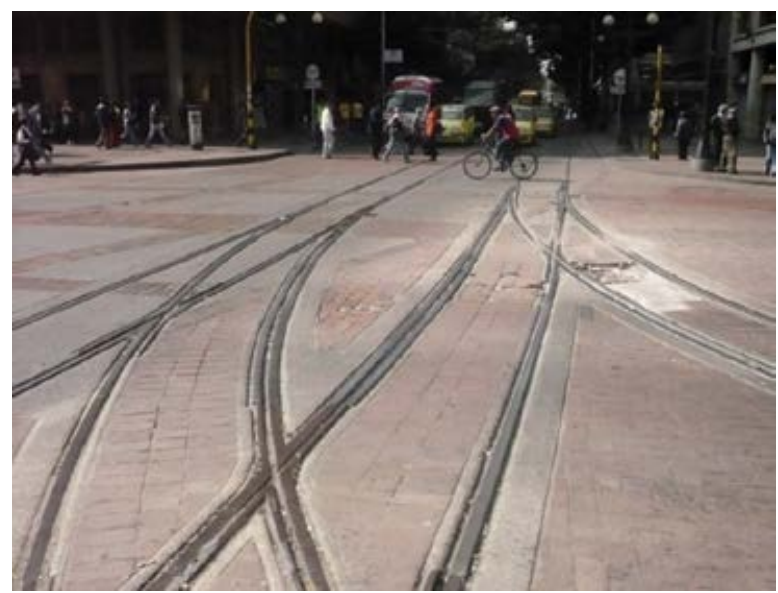

Figura 8. Carriles del tranvía antiguo en el centro de Bogotá

Fuente: fotografía del autor. 
La interpretación artística de Grau, por lo tanto, se explica casi por sí misma. Partiendo de las ideas de Rolf Reichardt, mencionadas en páginas anteriores, estas imágenes forman parte de la memoria visual de la mayoría de los colombianos hoy en día. Tanto es así que una mera alusión como el Tranvía incendiado basta (figura9) para "activar", o sea, recordar, los horrores del 9 de abril. Para los horrores de La Violencia, sin embargo, no hay lugar en tales "discursos visuales refinados" (Reichardt 2006, 226).

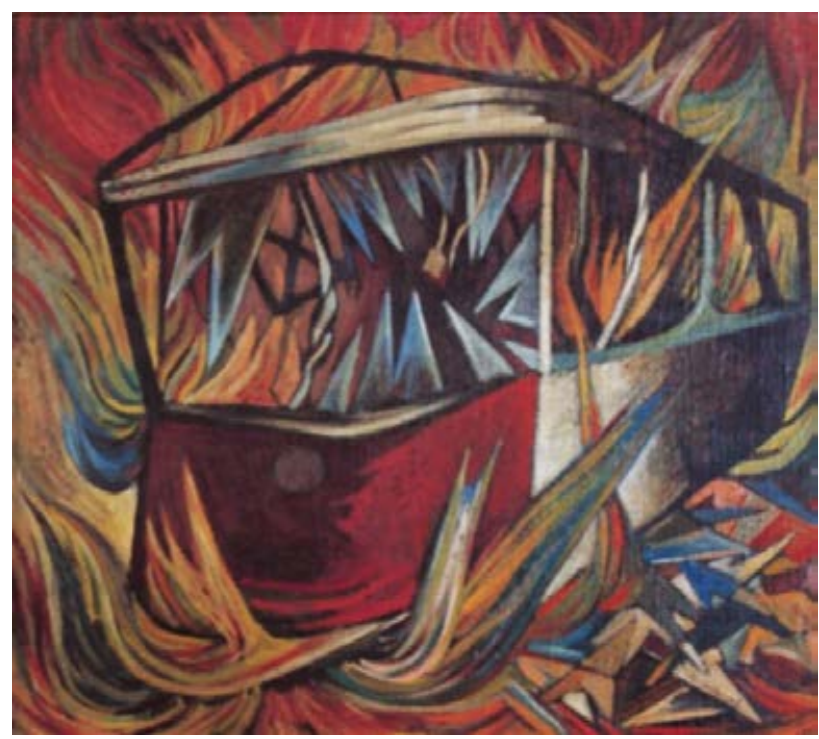

Figura 9. Enrique Grau, 1948, El tranvía incendiado, (óleo sobre tela, $51 \times 57 \mathrm{~cm}$ ) Fuente: Medina y Zea (1999).

\section{Conclusión}

En este ensayo quería mostrar que nuestra manera de ver los hechos del 9 de abril no solo tiene que ver con las "políticas del olvido" de los años cincuenta y sesenta, sino con la construcción de una memoria visual particular. Las imágenes desempeñaron y desempeñan un papel importante en el proceso de representar, interpretar y contextualizar los sucesos de aquel día. Como mostré, el 9 de abril fue visualizado ya muy temprano por algunos de los artistas más prolíficos del país, aunque no siempre de una manera diferenciada y contextualizada. Así, ni siquiera una pintora tan crítica como Débora Arango, cuyos cuadros muchas veces contenían denuncias explícitas contra la élite política, consiguió evitar el estereotipo de la "masa irracional y salvaje” y dejó las raíces de La Violencia en lo oscuro. En el caso de Obregón, 
la recepción de su cuadro resultaba ambigua porque las víctimas de la "masacre" podían ser interpretadas como la consecuencia de una revuelta sin lógica, sin razones y sin actores concretos. Se opaca entonces el hecho de que el 9 de abril era en realidad la primera culminación de una ola de violencia que estaba azotando el campo colombiano desde 1946. Por concentrarse en Bogotá y por marcar el inicio del conflicto con el asesinato de Gaitán, estas y otras imágenes forjaron nuestra manera descontextualizada de ver La Violencia. Los años de barbarie entre 1946 y 1963 son reducidos a "tranvías incendiados" y luchas entre la Jega y los chulavitas. No cabe ninguna duda de que estas iconografías del Bogotazo tuvieron un impacto profundo en la memoria visual de Colombia, mientras que La Violencia cayó en el olvido. Hoy en día, se trata de un "no lugar", sin nombre ni cronología concreta.

El mejor ejemplo de la continuada no representación de La Violencia son los museos de nuestros días, los cuales — con la excepción del Centro de Memoria de Bogotá- tampoco rompen con esta tradición reduccionista y selectiva. De todas maneras, la memoria es esencialmente eso: selección. Hay que olvidar para poder recordar (Ricoeur 2006, 448 y ss.). Lo cierto es que siempre habrá actores que intervienen en el proceso de construir memoria para definir que debería ser recordado, cómo debería ser recordado y con qué fin algún suceso debería ser transformado en lugar de memoria.

Aun así, los artistas aquí mencionados no necesariamente tenían la intención de reducir la violencia política de los años cuarenta y cincuenta al Bogotazo. Al contrario, pintores como Débora Arango y Alejandro Obregón se destacaron con varios cuadros magníficos que denuncian la violencia partidista en las zonas rurales. Más bien, por decisión de la élite política y cultural, estos cuadros nunca ganaron el mismo lugar destacado que las innumerables representaciones del 9 de abril. La descontextualización de los sucesos históricos fue tan exitosa que incluso un cuadro como La Violencia de Alejandro Obregón, expuesto en el Museo de Arte del Banco de la República en Bogotá, y el cual se inspiró en el paisaje impregnado de sangre y muerte del departamento del Quindío durante La Violencia, hoy en día es presentado como un "símbolo universal de denuncia de las guerras" (Medina 1999 c, 5). Considerando eso, y aunque no sea el juicio definitivo, el comentario de Gonzalo Sánchez sobre la inevitable reinterpretación venidera de los ecos de La Violencia parece acertado. A la final, solo nos quedará el 9 de abril, y sus significados siguen cambiando. 


\section{Bibliografía}

Alcaldía Mayor de Bogotá. 2012. "Alcalde Gustavo Petro inaugura Centro de Memoria del Distrito". http://www.bogotahumana.gov.co/index.php/noticias/ comunicados-de-prensa-alcalde-mayor/2767-alcalde-gustavo-petro-inaugura-centro-de-memoria-del-distrito

Antequera Guzmán, José Darío. 2011. La memoria histórica como relato emblemático. Bogotá: Rocca.

Braun, Herbert. 1985. The Assassination of Gaitán: Public Life and Urban Violence in Colombia. Madison: University of Wisconsin Press.

Braun, Herbert. 2008. Mataron a Gaitán: vida pública y violencia urbana en Colombia. Bogotá: Aguilar.

Bravo, Marta Elena y Carlos Arturo Fernández Uribe. 2006. Débora Arango en el Centro Cultural "Reyes Católicos”. Bogotá: Art Editions.

El Siglo. 1940. "Desafío al buen gusto", 10 de octubre.

Halbwachs, Maurice. 2004. La memoria colectiva. Zaragoza: Prensas Universitarias. Jaramillo, Carmen María. 2001. “Alejandro Obregón”. http://www.museo-nacional. gov.co/resena.html

Laverde, María Cristina. 2004. “Conversación con Débora Arango”. En Otras miradas, editado por Carmen María Jaramillo, 39-41. Bogotá: Ministerio de Relaciones Exteriores.

Londoño Calle, Viviana. 2011. "El mensaje de los muertos”. El Espectador, 7 de junio. Londoño Vélez, Santiago. 1997. Débora Arango: vida de pintora. Bogotá: Ministerio de Cultura.

Medina, Álvaro. 1999a. "El arte y la violencia colombiana en la segunda mitad del siglo xx”. En Arte y violencia en Colombia desde 1948, editado por Álvaro Medina y Gloria Zea, 10-120. Bogotá: Norma.

Medina, Álvaro. 1999b. "Obras y artistas del siglo xx en Colombia”. Credencial Historia 111:8-9.

Medina, Álvaro. 1999c. "Violencia”. Credencial Historia 111: 5.

Medina, Álvaro y Gloria Zea, editores. 1999. Arte y violencia en Colombia desde 1948. Bogotá: Norma.

Nora, Pierre. 1984-1992. Les lieux de mémoire. 3 vols. Paris: Gallimard.

Pécaut, Daniel. 2013. La experiencia de la violencia: los desafíos del relato y la memoria. Medellín: La Carreta Histórica. 
Reichardt, Rolf. 2006. "Bild- und Mediengeschichte". En Kompass der Geschichtswissenschaft, editado por Joachim Eibach y Günther Lottes, 219-230. Göttingen: Vandenhoeck \& Ruprecht.

Ricoeur, Paul. 2006. Memory, History, Forgetting. Chicago: The University of Chicago Press.

Sánchez, Gonzalo. 2006. Guerras, memoria e historia. Medellín: La Carreta Histórica.

Sánchez, Gonzalo. 2012. "El 9 de abril: una conmemoración reinventada”. El Espectador, 8 de abril.

Semana. 2006. "El perfil del asesino", 8 de abril.

Schuster, Sven. 2009. Die Violencia in Kolumbien: Verbotene Erinnerung? Der Bürgerkrieg in Politik und Gesellschaft, 1948-2008. Stuttgart: Heinz.

Warnke, Martin. 2003. "Politische Ikonografie". Historische Arbeitsblätter 2: 5-16.

Zambrano Pantoja, Fabio y Alfredo Iriarte. 1988. "Administración y servicios públicos”. En Historia de Bogotá, editado por Fabio Puyo Vasco, 37-84. Vol. 3. Bogotá.

Zea, Gloria. 1994. El museo de arte moderno de Bogotá: una experiencia singular. Bogotá: El Sello. 